UDC $57.044+57.085 .25$

\title{
An influence of complexes of therapeutic antisense oligodeoxynucleotides with cationic polymers on cell respiration
}

\author{
M. R. Kozak ${ }^{1}$, D. D. Ostapiv ${ }^{1}$, N. Y. Mitina², I. M. Petruh¹, K. A. Volianiuk², \\ A. S. Zaichenko 2 , V. V. Vlizlo ${ }^{3}$ \\ ${ }^{1}$ Institute of Animal Biology, NAAS of Ukraine \\ 38, Stusa Str., Lviv, Ukraine, 79034 \\ ${ }^{2}$ Lviv Polytechnic National University \\ 12, S. Bandery Str., Lviv, Ukraine, 79013 \\ ${ }^{3}$ Stepan Gzhytskyi National University of Veterinary Medicine and Biotechnologies of Lviv \\ 50, Pekarska Str., Lviv, Ukraine, 79010 \\ mariya_kozak@yahoo.com
}

Antisense-DNA technologies are new strategy for the treatment of prion infections. This strategy requires prolonged administrations of the drugs, which are likely to alter cell redox processes. Aim. The evaluation of cell survival and intensity of oxidative processes in vitro under the influence of antisense-oligodeoxynucleotides (asODNs) as cell prion inhibitors $\left(\mathrm{PrP}^{\mathrm{C}}\right.$ ) complexed with cationic polyelectrolyte. Methods. Free diffusion in agarose gel, study of cytotoxic action on model cells (bull semen), polarography and potentiometric measurement of oxygen uptake, statistical analysis. Results. Poly(dimethylaminoethyl methacrylate)[-]based surfactants form complexes with asODNs. Polyethylene glycol containing surfactants increase oxygen uptake by cells: by $18 \%$ (VI), by $37 \%$ (IV) and 2.6-fold for $\mathbf{V}$. An addition of the IV-asODNs complex into [the] cell medium did not affect the oxygen absorption; however, it increased reduction processes. Interpolyelectrolyte complex $\mathbf{V}$-asODNs increased the cell respiration by 1.95 times. VI separately increased the cell absorption of oxygen by $18 \%$ and in the complex with asODNs - by $36 \%$. VI possessed the lowest cytotoxicity. Conclusions. New cationic polyelectrolytes form complexes with asODNs. VI causes the smallest effect on the RedOx processes of model cells and possesses the lowest cytotoxic effect.

Ke y w o r d s: antisense oligodeoxynucleotides, polyelectrolyte complexes, cytotoxicity, redox processes, prion.

(C) 2021 M. R. Kozak et al.; Published by the Institute of Molecular Biology and Genetics, NAS of Ukraine on behalf of Biopolymers and Cell. This is an Open Access article distributed under the terms of the Creative Commons Attribution License (http://creativecommons.org/licenses/by/4.0/), which permits unrestricted reuse, distribution, and reproduction in any medium, provided the original work is properly cited 


\section{Introduction}

The pathogenesis of prion infections is associated with the synthesis and aggregation of the cellular form of prion $\left(\mathrm{PrP}^{\mathrm{C}}\right)$. Therefore, it is assumed that the elimination or reduction of $\mathrm{PrPC}^{\mathrm{C}}$ synthesis in the body will prevent the development and manifestation of transmissible spongiform encephalopathy [1-2].

The possible ways to inhibit the protein synthesis include the use of antisense oligodeoxynucleotides (asODNs), which are complementary to a specific region of mRNA [2-4]. Antisense technology allows "turning off" the gene temporarily, which is useful for the development of an adequate strategy for the prevention and treatment of prion infections. Noteworthy, the nucleic acids due to the nucleases degradation activity and poor cellular delivery does not penetrate the cell membrane, which imposes serious restrictions on their use. The success of the use of antisense technology largely depends on the availability of appropriate carriers for asODNs. Cationic synthetic and natural polymers can be carriers for the delivery of genetic material to cells because through electrostatic interactions they effectively bind negatively charged DNA molecules [5]. Thus, they shield DNA from the enzyme degradation, prolong the residence time of genetic constructs in the body and facilitate their penetration into the cells [4]. This invented scheme for inhibition of the development and prevention of prion infections also requires constant drug administration $[2,4,6]$. Prolonged administration of the active substances likely alters the processes associated with ATP resynthesis and protein phosphorylation in cells. The alteration of redox homeostasis is recog- nized as a significant cause of male factor infertility. Many factors can deregulate this complex network in animals, including exposure to chemicals, toxins and diseases [7].

The aim of the study was to evaluate qualitatively the ability of polymeric carriers to bind antisense oligodeoxynucleotides, and to investigate their effect on the cell oxidative processes in vitro.

\section{Materials and Methods}

Solvents: dimethylformamide (DMF), 1,4-dioxane, acetone, $n$-hexane were purchased from Merck (Darmstadt, Germany). Monomers: 2-(dimethylamino)ethyl methacrylate (DMAEM), 2-aminoethyl methacrylate hydrochloride (AEM), butyl acrylate (BAC), $\mathrm{N}$-vinylpyrrolidone (NVP) were received from Sigma Aldrich and used without purification. Azoisobutyronitrile (AIBN), poly(ethylene glycol), $\mathrm{Mn}=550$ (PEG), ammonium cerium (IV) nitrate were received from Aldrich Chemical and used without purification. Peroxy-containing chain transfer agent 1 -isopropyl-3(4)-[1-(tert-butylperoxy)-1-methylethyl]benzene (MP) was synthesized as described earlier [8].

$\mathrm{NaF}$, amytal, sodium azide, disodium ethylenediaminetetraacetic were purchased from Merck (Darmstadt, Germany).

Synthesis of poly(DMAEM)-MP (I). AIBN (2 mmol) was dissolved in ethyl acetate (15 mL). DMAEM (112 mmol) and MP (30 mmol) were added, and the mixture was purged with Argon. Polymerization was carried out at $70{ }^{\circ} \mathrm{C}$ for $6 \mathrm{~h}$. The conversion was $65-$ $70 \%$, as determined from dilatometer and 
gravimetric measurements [9]. The target product was precipitated from acetone into hexane three times and dried in vacuum.

In ${ }^{1} \mathrm{HNMR}$, the DMAEM units offered the following signals: skeletal $-\mathrm{CH}_{2}-$ at $1.75 \mathrm{ppm}$; fragments $-\mathrm{N}\left(\mathrm{CH}_{3}\right)_{2}$ at $2.30 \mathrm{ppm} ;-\mathrm{CH}_{2}$ $\mathrm{N}\left(\mathrm{CH}_{3}\right)_{2}$ at $2.552 .62 \mathrm{ppm} ;-\mathrm{C}(\mathrm{O})-\mathrm{CH}_{2}-$ at $4.2 \mathrm{ppm}$ and $\mathrm{CH}_{3}-\mathrm{C}-$ at $1.32 \mathrm{ppm}$. Signals from the benzene ring at 7.05-7.22 ppm and the t-butyl group at 1.14-1.18 ppm indicated availability of terminal peroxide fragment.

Synthesis of poly(DMAEM-co-BAC)-MP (II). AIBN (2 mmol) was dissolved in ethyl acetate $(15 \mathrm{~mL})$. DMAEM (112 mmol), BAC (10 mmol) and MP (30 mmol) were added, and the mixture was purged with Argon. Polymerization was carried out at $70{ }^{\circ} \mathrm{C}$ for $6 \mathrm{~h}$. The conversion was $65-70 \%$. The target product was precipitated from acetone into hexane three times and dried in vacuum.

In ${ }^{1} \mathrm{HNMR}$, the DMAEM units offered the following signals: skeletal $-\mathrm{CH}_{2}-$ at $1.75 \mathrm{ppm}$; fragments $-\mathrm{N}\left(\mathrm{CH}_{3}\right)_{2}$ at $2.30 \mathrm{ppm} ;-\mathrm{CH}_{2}-$ $\mathrm{N}\left(\mathrm{CH}_{3}\right)_{2}$ at $2.55-2.62 \mathrm{ppm} ;-\mathrm{C}(\mathrm{O})-\mathrm{CH}_{2}-$ at 4.2 ppm and $\mathrm{CH}_{3}-\mathrm{C}-$ at $1.32 \mathrm{ppm}$. The $\mathrm{BAC}$ units signal is $-\mathrm{O}-\mathrm{CH}_{2}-3.95 \mathrm{ppm}$. The presence of the terminal peroxide group is confirmed by signals of protons of the benzene ring (7.22 and $7.14 \mathrm{ppm})$, t-butyl $\mathrm{C}\left(\mathrm{CH}_{3}\right)_{2} \mathrm{OOC}\left(\mathrm{CH}_{3}\right)_{3}$ (1.1 ppm) and $\mathrm{C}\left(\mathrm{CH}_{3}\right)_{2} \mathrm{OOC}\left(\mathrm{CH}_{3}\right)_{3}(1.50 \mathrm{ppm})$.

Synthesis of poly(DMAEM)-blockpoly(NVP-co-BAC-co-AEM) (III). Synthesis of the block copolymers was carried out via solution polymerization of the NVP, BAC, and AEM initiated by $\mathbf{I}$. Monomer mixture NVP (110 mmol), BAC (27 mmol) and AEM (11 mmol) were added to the solution of $\mathrm{pD}$ MAEM-MP (0.45 g) in DMF (15 mL). Then the mixture was stirred at $80^{\circ} \mathrm{C}$ for $24 \mathrm{~h}$ under the Argon atmosphere. The resulting block copolymers were precipitated three times from acetone to hexane, separated, purified via dialysis and dried under vacuum.

${ }^{1} \mathrm{H}$ NMR of the III: the polymeric skeletal $-\mathrm{CH}_{2}-$ at $1.92-1.75 \mathrm{ppm}$; the DMAEM fragments units demonstrated the following signals: $-\mathrm{N}\left(\mathrm{CH}_{3}\right)_{2}$ at $2.30 \mathrm{ppm},-\mathrm{C}(\mathrm{O})-\mathrm{CH}_{2}-$ at 4.1-4.1 ppm, $\mathrm{CH}_{3}-\mathrm{C}-$ at $1.34 \mathrm{ppm}$ and $\mathrm{Ar}-\mathbf{H}$ at 7.05-7.20 ppm; the poly(NVP-co-BAC-coAEM) fragments units demonstrated the following signals the VP units: skeletal- $\mathrm{CH}_{2}-$ at 1.23 ppm, skeletal $-\mathrm{CH}-$ at 3.64 and 3.79 ppm; pyrrolidone ring: a-CH -3.37 ppm, b-CH $-\mathbf{C H}_{2}-$ $2.1 \mathrm{ppm}, \mathrm{c}-\mathrm{CH}_{2}-$ at 2.25 and $2.35 \mathrm{ppm}$; signals the BAC units:- $\mathrm{O}-\mathrm{CH}_{2}-3.95$ ppm; signals the AEM units: $\mathrm{NH}_{2}-\mathrm{CH}_{2}-\mathrm{CH}_{2}-\mathrm{O}$ at 3.03 ppm and $\mathrm{NH}_{2}-\mathrm{CH}_{2}-\mathrm{CH}_{2}-\mathrm{O}$ at $4.1 \mathrm{ppm}$.

MP-poly(DMAEM)-PEG-poly(DMAEM)$M P(\boldsymbol{I} \boldsymbol{V}-\boldsymbol{V I})$. Tri-block-copolymers IV-VI were synthesized via polymerization in water in the flask protected from light at $291 \mathrm{~K}$. DMAEM (0.45 mol/L), $0.08 \mathrm{~mol} / \mathrm{L}$ PEG, MP and concentrated nitric acid were dissolved in $20 \mathrm{~mL}$ of solvent. The mixture was purged by argon. The reaction was started by injecting the Ce(IV) salt $(0.076 \mathrm{~mol} / \mathrm{L})$ dissolved in $5 \mathrm{~mL}$ solvent. Polymerization was carried out for $4 \mathrm{~h}$. The polymer was washed with acetone and dried under vacuum. Polymer $\mathbf{V}$ was not purified from $\mathrm{Ce}$ ions.

${ }^{1} \mathrm{HNMR}$ of polymers: PEG fragments are confirmed by signals at 3.51 and 3.44 ppm corresponding to protons of $\mathrm{CH}_{2}$-groups of the main chain. DMAEM link: the protons of the methyl groups $-\mathrm{CH}_{2}-\mathrm{N}\left(\mathrm{CH}_{3}\right)_{2}$ appear as an intense peak at $2.79 \mathrm{ppm}$; a peak at $4.23 \mathrm{ppm}$ corresponds to methylene groups $-\mathrm{CH}_{2}-$ $\mathrm{CH}_{2} \mathrm{~N}\left(\mathrm{CH}_{3}\right)_{2}$; the signals of the protons of the 


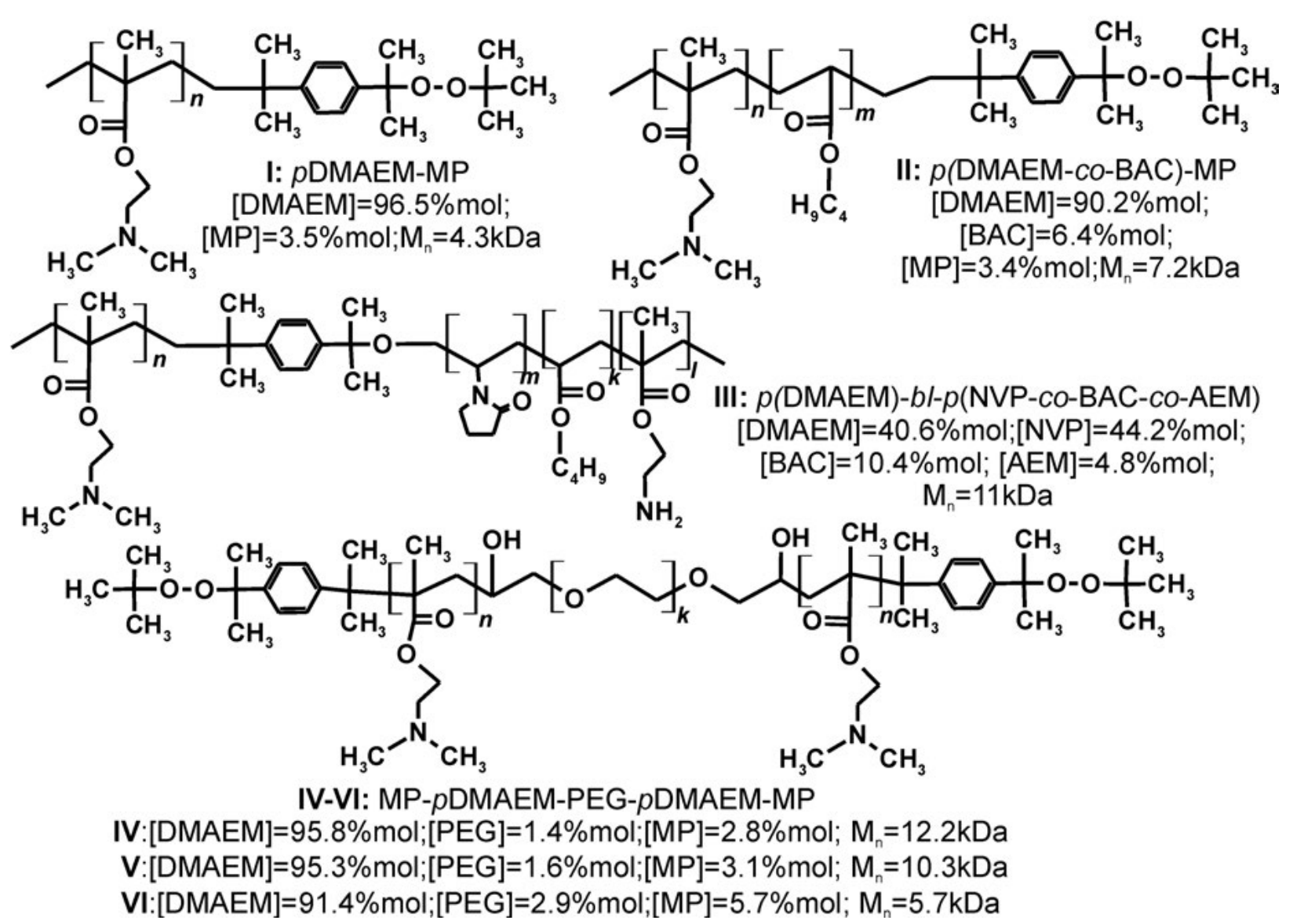

Fig. 1. Structures of polymers

side methyl group - $\mathrm{CH}_{2}-\mathrm{C}\left(\mathrm{CH}_{3}\right)$ - appear in the region of $1.18 \mathrm{ppm}$, and the protons of the methylene group of the main chain — at $1.91 \mathrm{ppm}$. The presence of the peroxide group is confirmed by signals of the benzene ring ( 7.22 and $7.14 \mathrm{ppm})$, tert-butyl $\mathrm{C}\left(\mathrm{CH}_{3}\right)_{2} \mathrm{OOC}\left(\mathrm{CH}_{3}\right)_{3}$ $(1.1 \mathrm{ppm})$ and $\mathrm{C}\left(\mathrm{CH}_{3}\right)_{2} \mathrm{OOC}\left(\mathrm{CH}_{3}\right)_{3}(1.50 \mathrm{ppm})$.

The asODNs-polymer complexes were synthesized by the method [10]. Polymer ( $8 \mathrm{mg})$ was dissolved in $0.01 \mathrm{M} \mathrm{HCl}, \mathrm{pH}$ of the solution 7.4 and volume $10 \mathrm{ml} .0 .5 \mathrm{~mL}$ of polymer solution were mixed with $0.5 \mathrm{~mL}$ of aqua solu- tion of asODNs $(\mathrm{C}=20 \mathrm{nmol} / \mathrm{mL})$. Mixtures were incubated for $30 \mathrm{~min}(298 \mathrm{~K})$.

Polymer cytotoxicity. The effect of polymers and their complexes with asODNs on the cell survival and oxidative processes was studied in vitro on sperm. The ejaculates were collected from bulls: $\mathrm{V}=2-4 \mathrm{~mL} ; \mathrm{C}=0.8$ $1.3 \cdot 10^{9}$ cells $/ \mathrm{mL}$; vitality $=70 \%$ or more. To the sperm suspension $(200 \mu \mathrm{L}) 10 \mu \mathrm{L}$ of polymers in concentrations of $0.05 \%, 0.5 \%$ and $1 \%$ were added. Sperm survival (h) was assessed under a microscope $(\times 200)$ until the cessation of rectilinear translational motion [5]. 
Detection of complexes formation as ODNspolymers. The ability of polymers to bind oligonucleotides was determined by the method of free diffusion in agarose gel $[5,11]$.

Cellular metabolic activity was determined for the cells after 96 hours of the cultivation. The intensity of oxygen consumption by cells was established polarographically (ng-atoms $\mathrm{O}_{2} \cdot \mathrm{min}^{-1} \cdot \mathrm{mL}^{-1}$ cell suspension) using the Clark electrode, which was mounted in a thermostated container $\left(\mathrm{t}=38.5^{\circ} \mathrm{C}\right)$. The cell respiration was measured using standard polarographic techniques with a Clark-type electrode. Cell reduction processes were measured potentiometrically $\left(\mathrm{mV} / \mathrm{min} / 10^{6}\right.$ cells $)$ [12] using open system of microelectrodes [13]. The fraction of oxygen consumed by aerobic glycolysis was determined using an inhibitor of the specified metabolic pathway $\left(\mathrm{NaF} ; 10^{-3} \mathrm{M}\right)$. The fraction of oxygen consumed by the NAD-dependent chain of the electron transport chain was detected using amytal $\left(5 \cdot 10^{-3} \mathrm{M}\right)$ and sodium azide $\mathrm{NaN}_{3}\left(5 \cdot 10^{-2} \mathrm{M}\right)$. The intensity of free radical oxidation of unsaturated fatty acids was determined using $\mathrm{Na}_{2} \operatorname{EDTA}\left(0.6 \cdot 10^{-3} \mathrm{M}\right)$. The study of the specific oxygen uptake rate of cells was carried out at $38.5^{\circ} \mathrm{C}$ in phosphatebuffered saline (PBS: $\mathrm{NaCl}-0.8 \mathrm{~g} ; \mathrm{KCl}-$ $0.02 \mathrm{~g} ; \mathrm{Na}_{2} \mathrm{HPO}_{4}-0.11 \mathrm{~g} ; \mathrm{KH}_{2} \mathrm{PO}_{4}-0.02 \mathrm{~g}$; $\mathrm{MgCl}_{2}-0.01 \mathrm{~g} ; \mathrm{H}_{2} \mathrm{O}$ to $\left.100 \mathrm{~mL} ; \mathrm{pH}-7.4\right)$. $0.9 \mathrm{~mL}$ of PBS and $0.1 \mathrm{~mL}$ of cell suspension were introduced into the thermostatic container.

\section{Result and Discussion}

The free diffusion in agarose gel is a rapid and useful method for the screening of suitable transporter of therapeutic nucleic acid compounds, including asODNs $[5,11]$. It was es-

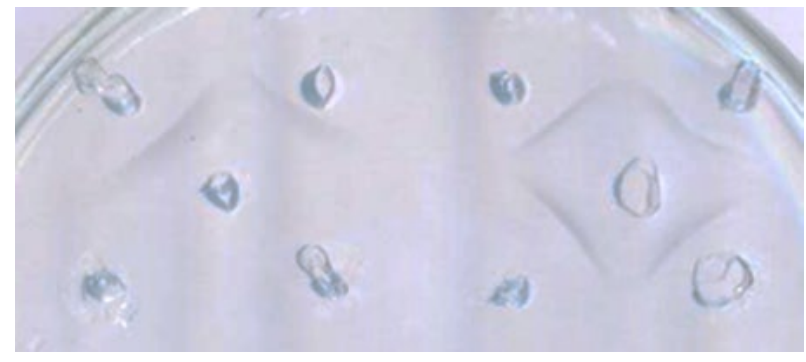

Fig. 2. Detection of polymer-asODNs complex. The method of free diffusion in agarose gel. The formed complexes are visible as characteristic precipitation arcs.

tablished that the polymers based on DMAEM, which are characterized by a positive charge, form complexes with asODNs. The formed complexes are visible as characteristic precipitation arcs (Fig. 2).

Polymer $\mathbf{V}$ has slow diffusion, which indicates its higher molecular weight, apparently due to the presence of cerium ions.

Polymers that showed the ability to bind asODNs were tested for their cytotoxic effects on cells. The cell survival was 72 hours for polymers I, II and III, and 96 hours for polymers IV and V. Polymer VI was characterized by the lowest cytotoxicity. Cell survival under VI exposure was 120 hours indicating its low toxicity.

We measured the redox processes caused by the polymers and their complexes with therapeutic asODNs, which decrease the $\mathrm{PrPC}^{\mathrm{C}}$ level [5]. The prion-infected transgenic mice overexpressing the hamster prion protein $(\mathrm{Tg} 7$ mice) suffer from mitochondrial respiratory deficits [14]. Mitochondrial respiration of cells/tissues is a significant proportion of total oxygen uptake. The cell respiration involves oxidation and reduction processes (redox). It was found that the polymers increase cel- 
lular oxygen uptake: I - by $9.1 \%$, II - by $21.3 \%(\mathrm{p}<0.05)$, and III - by $59.1 \%$ (p $<0.01$; Fig. 3, Table 1).

Simultaneously, polymer I increases the reduction capacity of cells two-fold $(\mathrm{p}<0.05)$. Polymer II does not change $(5.3 \pm 0.72 \mathrm{mV} /$ $\mathrm{min} / 10^{6}$ cells) [the] cell reduction capacity and III decreases it by $66.1 \%(\mathrm{p}<0.01)$. The Analysis of cell redox processes is characterized by strong correlation $(\eta=0.860)$ and moderate correlation $(\eta=0.599)$, respectively (Tables 1, 2).

In order to establish the effect of active substances on cell metabolism and ATP resynthesis, the intensity of substrate use and electron transport in the mitochondrial respiratory chain was assessed. In particular, $\mathrm{NaF}$ inhibits the conversion of phosphoglyceric acid into phosphopyruvic acid and therefore arrests glycolysis [15], amital inhibits the I complex of mitochondrial electron transport chain [16, 17], $\mathrm{NaN}_{3}$ is an inhibitor of cytochrome oxidase $[18,19]$. The inhibitors cause a gradual decrease of oxygen uptake. At the same time, depending on the intensity of electron trans-

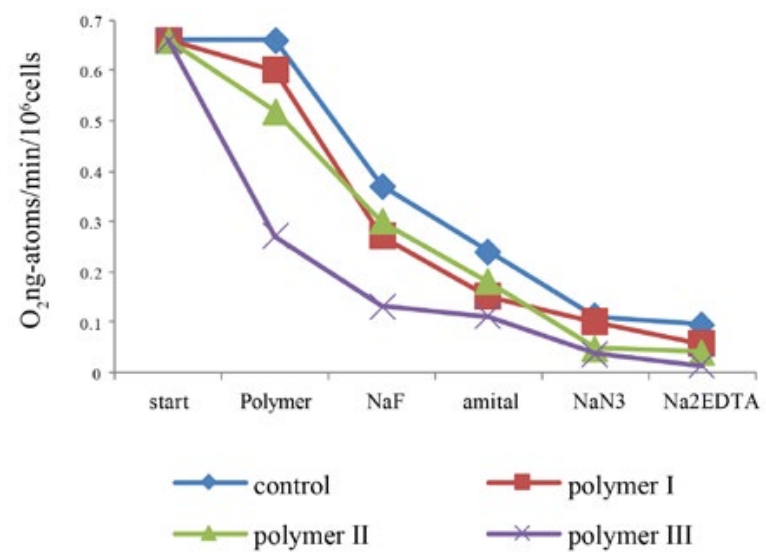

port in the respiratory chain, there are different magnitudes of the flow of electrons/protons into the extracellular space and, therefore, different reduction processes. During addition of inhibitors, the polymers depress both the use of substrates and the transport of electrons in the mitochondrial respiratory chain to a greater extent than in control. In particular, $\mathrm{NaF}$ together with polymer I reduce respiratory activity by 2.2 times $(\mathrm{p}<0.05)$, and by $40.4 \%(\mathrm{p}<0.001)$ in control (without polymers). Sequential addition of inhibitors: amytal, $\mathrm{NaN}_{3}$ and $\mathrm{Na}_{2}$ EDTA gradually reduces the oxygen consumption by cells, respectively, by $44.5 \%, 33.3 \%$ and $43.0 \%$. Similarly, the reduction ability of cells decreases: by $32.0 \%$ under NaF influence, by $19.2 \%$ - under amytal and by $51.0 \%$ under $\mathrm{NaN}_{3}$, but adding $\mathrm{Na}_{2}$ EDTA causes an increase by $14.8 \%$ (Fig. 3). The effect of $\mathrm{NaF}$ under the action of II is manifested by $42.4 \%$ decrease of the oxidation process, whereas the sequential addition of amytal, $\mathrm{NaN}_{3}$ and $\mathrm{Na}_{2}$ EDTA inhibits this process by 12.7 times. The reduction processes of cells with the ad-

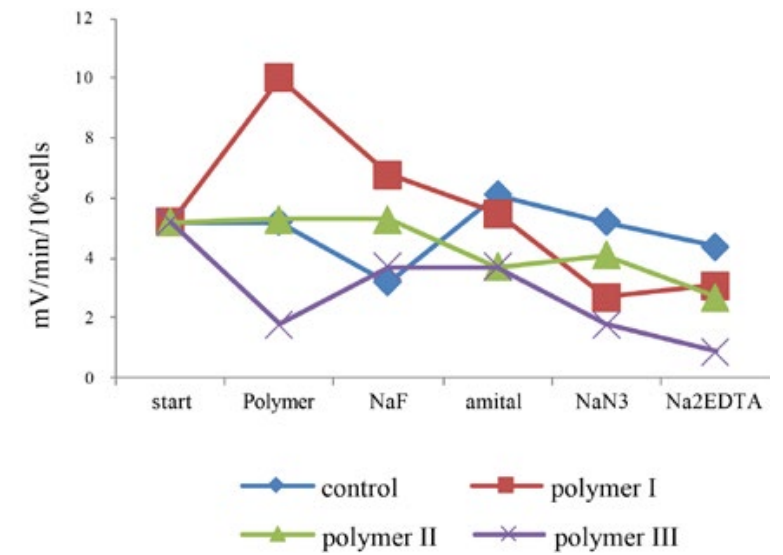

Fig. 3. Redox processes in cells under the action of polymer I, II and III. 
Table 1.Oxidation processes in cells under the action of polymer I, II and III.

\begin{tabular}{|l|c|c|c|c|c|}
\hline & \multirow{2}{*}{ control } & \multicolumn{3}{|c|}{ polymers } & \multirow{2}{*}{$\eta$} \\
\cline { 3 - 5 } & & I & II & III & \\
\hline Oxidation, $\mathrm{O}_{2}$ & $0.66 \pm 0.06$ & $0.60 \pm 0.10$ & $0.52 \pm 0.06$ & $0.27 \pm 0.11$ & 0.599 \\
$\mathrm{NaF}$ & $0.37 \pm 0.014$ & $0.27 \pm 0.060$ & $0.30 \pm 0.105$ & $0.13 \pm 0.048$ & 0.602 \\
$\mathrm{Amytal}$ & $0.24 \pm 0.007$ & $0,15 \pm 0.038$ & $0.18 \pm 0.080$ & $0.11 \pm 0.030$ & 0.487 \\
$\mathrm{NaN}_{3}$ & $0.11 \pm 0.018$ & $0.10 \pm 0.019$ & $0.047 \pm 0.0026$ & $0.037 \pm 0.024$ & 0.672 \\
$\mathrm{Na}_{2}$ EDTA & $0.094 \pm 0.017$ & $0.057 \pm 0.011$ & $0.041 \pm 0.024$ & $0.013 \pm 0.002$ & 0.730
\end{tabular}

Table 2. Reduction processes in cells under the action of polymer I, II and III.

\begin{tabular}{|l|l|l|l|l|l|}
\hline \multirow{2}{*}{ Reduction } & \multicolumn{1}{|c|}{ control } & \multicolumn{3}{|c|}{ Polymers: } & \multirow{2}{*}{$\eta$} \\
\cline { 3 - 5 } & & \multicolumn{1}{|c|}{ I } & \multicolumn{1}{|c|}{ II } & III & \\
$\mathrm{NaF}$ & $5.2 \pm 0.50$ & $10.0 \pm 1.68$ & $5.3 \pm 0.72$ & $1.8 \pm 0.83$ & 0.860 \\
Amytal & $3.2 \pm 0.34$ & $6.8 \pm 1.18$ & $5.3 \pm 0.72$ & $3.7 \pm 1.63$ & 0.620 \\
$\mathrm{NaN}_{3}$ & $6.1 \pm 1.34$ & $5.5 \pm 1.29$ & $3.7 \pm 0.98$ & $3.7 \pm 1.40$ & 0.439 \\
$\mathrm{Na}_{2}$ EDTA & $5.2 \pm 1.98$ & $2.7 \pm 1.47$ & $4.1 \pm 0.11$ & $1.8 \pm 0.50$ & 0.572 \\
& $4.4 \pm 0.25$ & $3.1 \pm 0.52$ & $2.7 \pm 0.67$ & $0.87 \pm 0.63$ & 0.802
\end{tabular}

dition of II and the use of inhibitors of both glycolysis and mitochondrial respiratory chain were almost unchanged. The range was from 3.7 to $5.3 \mathrm{mV} / \mathrm{min} / 10^{6}$ cells. $\mathrm{Na}_{2}$ EDTA decreased oxygen uptake by $49.1 \%(p<0.05)$ compared to the initial value (Fig. 3). Polymer III reduced redox potentials (Fig. 3). The analysis of the effect of polymers on the respiratory activity of cells in vitro shows that the polymer I causes the accumulation of protons in the extracellular space, but the penetration into the cells has low impact on the oxidation processes. Polymer II apparently penetrates the membranes and activates oxygen consumption and almost does not change the outflow of protons from cells. Polymer III stimulates both oxidation processes and the flow of electrons into the extracellular space. Polymer I inhibits the aerobic glycolysis and increases the sensitivity of this process to the influence of the inhibitor. Inhibition of aerobic glycolysis is accompanied by a double accumulation of protons in the extracellular space. By adding polymer II, the effect of inhibitors on the ATP resynthesis is similar to the control. However, during the inhibition of the NAD-dependent link in the mitochondrial respiratory chain, the flow of electrons increases in contrast to the control, where an increase of the space potential was found. Polymer III, after activation of oxidation processes, reduces the sensitivity to the inhibitors of both aerobic glycolysis and electron transport links in the mitochondrial respiratory chain.

Polymers IV and VI, which are derived from polymer I and contain PEG, reduce the cell oxygen uptake by $53.2 \%$ and $34.6 \%$, respectively. Polymer $\mathbf{V}$ increases the cell oxygen uptake by $23.9 \%$ (Fig. 4 A). 

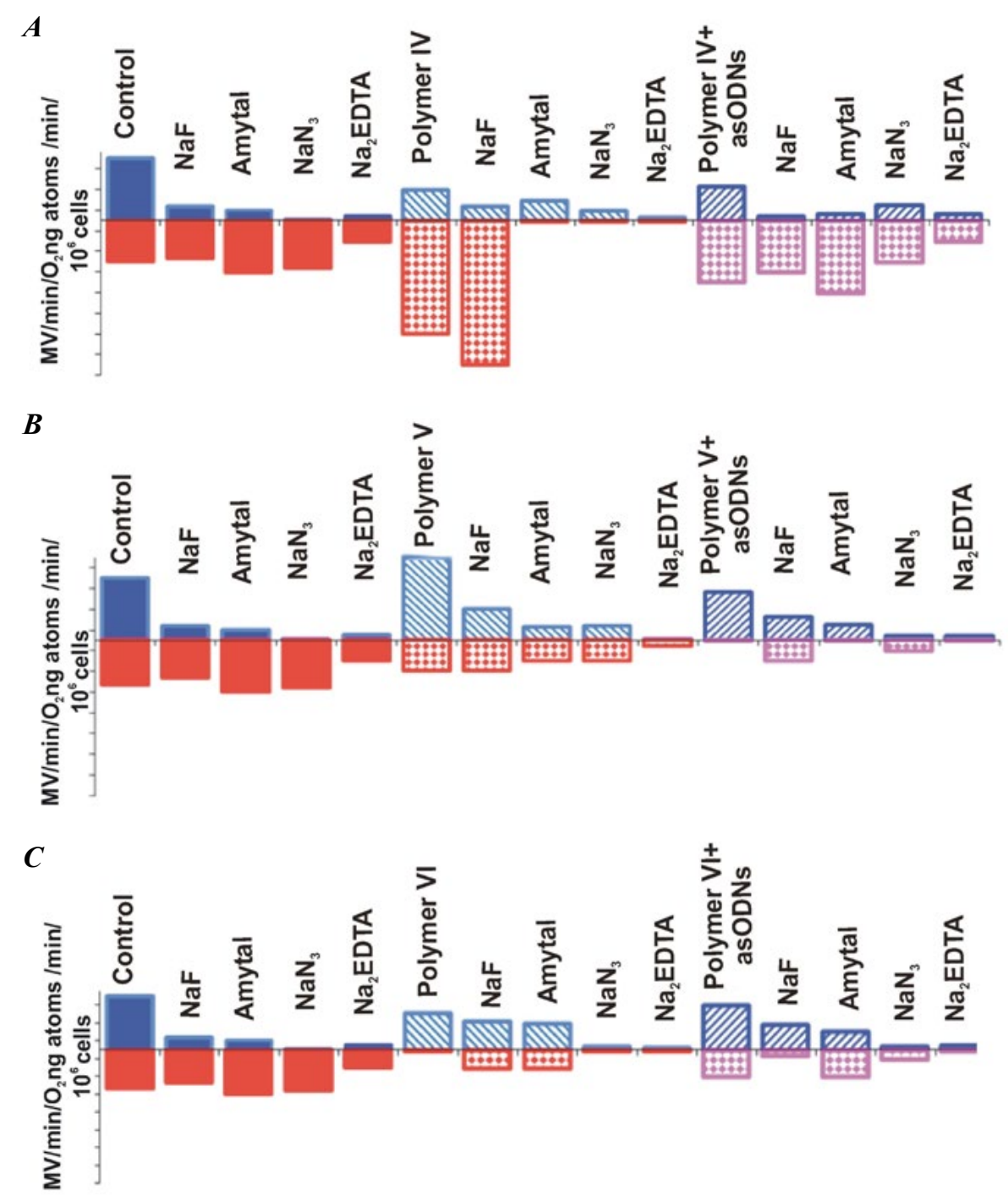

Fig. 4. Redox processes in cells under the action of polymers IV $(\boldsymbol{A}), \mathrm{V}(\boldsymbol{B})$ and VI $(\boldsymbol{C})$ alone and in complexes with asODNs.

The presence of cerium ions in the $\mathbf{V}$ affects the membrane structure of cells and modifies them [20,21], which provides penetration and use of exogenous substrates. The addition of IV to the sperm suspension stimulated (or caused) the flow of positively charged particles (protons) into the extracellular environment and, conversely, the additions of $\mathbf{V I}$ and $\mathbf{V}$ were characterized by the changes in cell metabolism, accompanied by the formation of negatively charged particles and their accumulation in the extracellular space.

IV-asODNs and VI-asODNs complexes do not change the intensity of cellular respiration, compared with separately added polymers. We suggest that the reducing of the im- 
pact on cells by these polymers in combination with asODNs happens due to already bound active groups of the polymers. The cell membranes of mammalian are negatively charged [22]. The free active groups of cationic polymers obviously are able to interact with the components of negatively charged cell membranes, change their structure, disrupt integrity and, accordingly, have a stronger effect on redox processes in cells. However, the $\mathbf{V}-$ asODNs complex, apparently due to the modification of membranes, penetrates into the cells and reduces the redox processes. With the addition of IV the potential of cell medium increased by 2.5 times, and with $\mathbf{V}$ and VI decreased equally by $30.3 \%$, compared to the control. IV-asODNs complex does not change the cell oxidation, compared to IV without asODNs, but it increases the reduction processes (fig. 4 A). Similarly, the cell oxidation processes were at the same level during addition of VI-asODNs complex or polymer VI ( $0.5 \mathrm{ng}$-atom $\mathrm{O}_{2} / \mathrm{min} / 10^{6}$ cell), and the reduction processes increased to $3.0 \mathrm{mV} / \mathrm{min} / 10^{6}$ cell (Fig. $4 \mathrm{C}$ ). V-asODNs complex reduces both cell oxygen uptakes by $45.2 \%$ and cell reduction processes by $96.7 \%$, compared to separately added $\mathbf{V}$ (Fig. 4 B).

After the addition of $\mathrm{NaF}$ to cultural mediums with IV and IV-asODNs, the absorption of oxygen decreased by 2.1 and 8.2 times respectively. The addition of $\mathrm{NaF}$ also reduces the respiratory activity together with the influence of other polymeric compounds and their complexes with asODNs. During the addition of amital to the cell medium with IV or with IV-asODNs complex, the formation of oxygen in a polarographic container was detected. At the same time, in the presence of IV the flow of charged particles is almost equal to $0(0.001$ $\mathrm{mV} / \mathrm{min} / 10^{6}$ cell). Complexes IV-asODNs and VI-asODNs stimulate an increase of space potential, respectively, by 29.4 and $80.0 \%$. During the test of VI, the reduction processes do not change $\left(2.0 \mathrm{mV} / \mathrm{min} / 10^{6}\right.$ cells $)$. Under the action of $\mathbf{V}$ and its complex with asODNs the reduction processes decrease by 33.4 and $99.9 \%$, respectively.

Inhibition of the terminal link of the mitochondrial respiratory chain by $\mathrm{NaN}_{3}$ in the presence of $\mathbf{I V}$-asODNs and $\mathbf{V}$ led to the release of oxygen into the cell environment. At the same time, the addition of amytal to the cell with IV and VI almost completely inhibits the flow (outflow) of charged particles (protons and electrons) from the NAD-dependent path of electron transport in the mitochondrial electron transport chain, which is manifested by a decrease of the potential to zero. The addition of amytal to the cell with $\mathbf{V}$ does not change the potential $\left(2.0 \mathrm{mV} / \mathrm{min} / 10^{6}\right.$ cells $)$, and in the presence of both $\mathbf{I V}$-asODNs and VI-asODNs decreases it. The addition of $\mathrm{Na}_{2}$ EDTA to cells with polymers both alone and in complexes with asODNs leads to an inhibition of reduction processes. It was detected that IV and IV-asODNs mostly inhibit aerobic glycolysis and stimulate the flow of protons into the extracellular space. These compounds together with amytal stimulate the generation of oxygen in a polarographic container. It is known that the blocking of the electron transport can lead to the formation of $\mathrm{O}_{2}{ }^{--}$[23-25]. Probably, the polymer IV and the complex IV-asODNs change the structure of membranes, penetrate into cells and enhance the inhibitory action of amytal. Generation of the active form of oxygen $\left(\mathrm{O}_{2}{ }^{--}\right)$by the mito- 
chondrial respiratory chain is one of the causes of membrane destructions [26]. Therefore, the use of IV and $\mathbf{V}$, both alone and in combination with asODNs, can cause changes in cell structure and stimulate the processes of free radical oxidation and $\mathrm{O}_{2}{ }^{-}$- formation. However, the effect of these compounds on the structures and metabolism is "mild", as their action ensures the survival of cells for 96 hours. The least toxic for cells is the polymer VI and its complex with asODNs. These compounds support aerobic glycolysis, with a weak effect on individual links of electron transport in the mitochondrial respiratory chain. Obviously, after penetration through the membrane into the cell, the polymer VI and VI-asODNs complex are able to normalize the use of endogenous substrates and provide resynthesis of ATP, high maintaining mobility and survival for 120 hours.

\section{Conclusions}

Polycationic polymers, which are based on DMAEM, form the complexes with prion inhibitors - antisense oligodeoxynucleotides. Polymers differed in their effect on REDOX processes and cytotoxicity. Polymer VI is characterized by the lowest cytotoxicity and minimal effect on redox processes in cells. Polymer VI is the most suitable transporter of asODNs for inhibition of the synthesis of physiological prion in animal cells.

\section{REFERENCE}

1. Nicoll AJ, Collinge J. Preventing prion pathogenicity by targeting the cellular prion protein. Infect. Disord Drug Targets. 2009; 9(1):48-57.

2. Susol NU. Influence of complexes of antisenseoligonucleotides with polymeric carriers on content of cellular prion in rat organs. Studia Biologica. 2017; 11(1):59-66.

3. Stein CA, Cohen JS. Oligodeoxynucleotides as inhibitors of gene expression: a review. Cancer Res. 1988; 48(10): 2659-68.

4. Stadnyk VV, Izyumova LA, Rzhepeckyy YuA, Mayor ChYa, Verbitskyy PI, Vlizlo VV. Antisense oligonucleotides as potential drugs for prophylaxis of prion infections. Ukr Biochem J. 2009; 81(4):112-116.

5. Kozak MR, Ivanytska LA, Zaichenko OS, Ostapiv DD, Vlizlo $V V$. Detection of complexes of oligodeoxynucleo-tides with polymericcarriers. Biotechnol Acta. 2013;6(5): 94-9.

6. Ivanytska L, Stadnyk V, Kozak M, Zaichenko A, Mitina $N$, Vlizlo $V$. Nonviral nanoscale-based delivery of antisense oligonucleotides enhances inhibition of the cellular prion expression in vivo. Bridges in Life Sciences 6th Annual Scientific Meeting, 8-11 April, 2011: Biopolym Cell. 2011; 27 (2 Supl): 136.

7. Peña FJ, O'Flaherty C, Rodríguez JMO, Cano FEM, Gaitskell-Phillips GL, Gil MC, Ferrusola CO. Redox Regula-tion and Oxidative Stress: The Particular Case of the Stallion Spermatozoa. Antioxidants. 2019; 8(11): 23.

8. Paiuk O, Mitina N, Slouf M, Pavlova E, Finiuk N, Kinash N, Karkhut A, Manko N, Gromovoy T, Hevus $O$, Shermolo-vich Yu, Stoika R, Zaichenko A. Fluorine-containing block/branched polyamphiphiles forming bioinspired com-plexes with biopolymers. Colloids Surf B Biointerfaces. 2019; 174:393400.

9. Dikyy MA. Synthesis and somerections of peroxide monomers - derivatives of isopropenyl benzene. Russ J Org Chem. 1981;17: 353.

10. Braun D, Cherdron H, Ritter H. PolymerSynthesis: TheoryandPractice: Fundamentals, Methods, Experiments; Springer: Heidelberg, Germany. 2004.

11. Kozak MR, Vlizlo VV, Ivanytska LA. Method for detection of poliplexoligodeoxynucleotides with cationic oligoelectrolytes. A utility model. № 70080, 2012.

12. Srivastava N. Protocols in semen biology (Comparing assays). Springer Nature Singapore, 2017; $285 \mathrm{p}$.

13. Chen Q, Vazquez EJ, Moghaddas S, Hoppel CL, Lesnefsky EJ. Production of reactive oxygen species 
by mito-chondria: central role of complex III. $J$ Biol Chem. 2003; 278:36027-31.

14. Faris $R$, Moore RA, Ward A, Sturdevant DE, Priola $S A$, Beemon $K L$. Mitochondrial respiration is impaired during late-stage hamster prion infection. J. Virol. 2017;91(18): 1-15.

15. Chang $I$. The action of iodoacetate and fluoride on the isolated rabbit's auricle. Exp Physiol. 1938; 137-47.

16. Esposti $M D$. Inhibitors of NADH-ubiquinone reductase: an overview. Biochim Biophys Acta. 1998;1364(2):222-35.

17. Choi $W$-S, Palmiter RD, Xia Z. Loss of mitochondrial complex I activity potentiates dopamine neuron death induced by microtubule dysfunction in a Parkinson's disease model. J Cell Biol. 2011; 192(5): 873-82.

18. Leary SC, Hills BC, Lyons CN, Carison CG, Michaud D, Kraft CS, Ko K, Glerum DM, Moyes CD. Chronic treatment with azide in situ leads to an irreversible loss of cytochrome $\mathrm{c}$ oxidase activity via holoenzyme dissoci-ation. J Biol Chem. 2002; 277(13):11321-8.

19. ZuoY, HuJ, XuX, GaoX, WangY, Zhu S. Sodiumazide induces mitochondria mediated apoptosis in PC12 cells through Pgc $1 \alpha$ associated signaling pathway. Mol Med Rep. 2019;19(3): 2211-9.

20. Zholobak NM. Àntibacterial effects of the volloidal (nanosized) cerium dioxide. Bulletin of problems in biology and medicine. 2015;3(123): 23-8.

21. Chen L, Yan C, Zheng Z. Functional polymer surfaces for controlling cell behaviors. Mater Today. 2018;21(1):38-59.

22. Pakulova OK, Klochkov VK, Kavok NS, Kostina IA, SopotovaAS, Bondarenko VA. Effect of rare-earthbased nanoparticles on the erythrocyte osmotic adaptation. Biophys Bull. 2017;37 (1):42-50.

23. Turrens $J F$. Mitochondrial formation of reactive oxygen species. $J$ Physiol. 2003; 552 (2): 335-44.

24. Nemoto S, Takeda K, Yu Z-X, Ferrans VJ, Finkel T. Role for mitochondrial oxidants as regulators of cellular metabolism. Mol Cell Biol. 2000;20 (19): 7311-8.

25. Zhao R, Jiang S, Zhang L, Yu Z-B. Mitochondrial electron transport chain, ROS generation and uncoupling. Int J Mol Med. 2019; 44: 3-15.
26. Orrenius S, Gogvadze V, Zhivotovsky B. Mitochondrial oxidative stress: Implications for cell death. Annu Rev Pharmacol Toxicol. 2007; 47:143-83.

\section{Вплив комплексів терапевтичних антисенс- олігодезоксинуклеотидів 3 катіонними полімерами на дихання клітин}

М. Р. Козак, Д. Д. Остапів, Н. С. Мітіна, К. А. Волянюк, І. М. Петрух, О. С. Заіченко, В. В. Влізло

Антисенс-ДНК технології - це нова стратегія лікування пріонних інфекцій. Ця стратегія вимагає тривалого введення ліків, які, ймовірно, змінять окисно-відновні процеси в клітинах. Мета. Оцінка виживання клітин та інтенсивності окисних процесів in vitro під впливом антисенс-олігодезоксинуклеотидами (асОДН) як інгібіторів фізіологічного пріонн $\left(\mathrm{PrP}^{\mathrm{C}}\right)$ у комплексі з катіонним поліелектролітом. Методи. Дослідження утворення комплексів між полімерами різної природи та асОДН - шляхом вільної дифузії в гелі агарози, цитотоксичної активності - на модельних клітинах (спермії бугая), поглинання кисню й відновну здатність клітин - полярографічно та потенціометрично, аналіз результатів дослідження - статистично. Результати. Встановлено, що полікатіонні полімери на основі диметиламіноетилметакрилату (DMAEM) утворюють комплекси з асОДН. Було встановлено, що всі досліджувані полімери, які містять поліетиленгліколь (ПЕГ), збільшують поглинання кисню клітинами: на $18 \%$ (VI), на 37 \% (IV) і в 2,6 рази для V. Додавання в клітинне середовище комплексу IV-acОДН не впливало на поглинання кисню, а посилювало процеси відновлення. Полімерний комплекс $\mathbf{V}$-асОДН збільшив дихання клітин в 1,95 рази, що нижче, ніж окрема дія $\mathbf{V}$ на ці клітини. Полімер VI окремо збільшував клітинну абсорбцію кисню на $18 \%$, а в комплексі з асОДН на 36 \%. Полімер VI продемонстрував найнижчу цитотоксичність. Висновки. Розроблено нові катіонактивні полімери, які утворюють комплекси з асОДН. Найменший вплив на окисно-відновні процеси модельних клітин (сперміїв) чинить сполука полімерної природи VI, для якої характерна низька цитотоксична дія in vitro. 
Кл ю ч о в і с л о в а: антисенс-олігодезоксинуклеотиди, поліелектролітні комплекси, цитотоксичність, окисно-відновні процеси, пріон.

\section{Влияние комплексов терапевтических антисенс-олигодезоксинуклеотидов с катионными полимерами на дыхание клеток}

М. Р. Козак, Д. Д. Остапив, Н. Е. Митина, К. А. Волянюк, И. М. Петрух, А. С. Заиченко, В. В. Влизло

Антисенс-ДНК технологии - это новая стратегия лечения протеинопатий, как прионные инфекции, болезнь Альцгеймера и другие. Эта стратегия требует длительного введения лекарств, которые, вероятно, изменят окислительно-восстановительные процессы в клетках. Цель. Оценка выживания клеток и интенсивности окислительных процессов in vitro под влиянием антисенс-олигодезоксинуклеотидов (асОДН) как ингибиторов физиологического приона $\left(\mathrm{PrP}^{\mathrm{C}}\right)$ в комплексе с катионным полиэлектролитом. Методы. Изучение цитотоксической активности на модельных клетках (сперматозоиды быка), исследование образования комплексов между полимером и асОДН путем свободной диффузии в геле агарозы, полярографическое и потенциометрическое измерения поглощения кислорода клетками, статистический анализ результатов исследования. Результаты. Установлено, что поликатионные полимеры на основе диметиламиноэтилметакрилата (ДМАЭМ) образуют комплексы с асОДН. Установлено, что все исследованные полимеры, содержащие полиэтиленгликоль (ПЭГ), увеличивают потребление кислорода клетками: на $18 \%$ (VI), на $37 \%$ (IV) и в 2,6 раза (V). Добавление в клеточную среду комплекса IV-acОДН не влияло на поглощение кислорода, но усиливало восстановительные процессы. Полимерный комплекс $\mathbf{V}$-асОДН увеличивал дыхание клеток в 1,95 раза, что ниже, чем действие отдельного полимера $\mathbf{V}$ на эти клетки. Полимер VI по отдельности увеличивал поглощение кислорода клетками на $18 \%$, а в комплексе с асОДН - на 36 \%. Полимер VI обладал наименьшей цитотоксичностью. Выводы. Разработаны новые катионные полимеры, способные формировать комплексы с асОДН. Полимер VI оказывает наименьшее влияние на окислительно-восстановительные процессы модельных клеток и имеет наименьшее цитотоксическое действие in vitro.

К л ю ч е в ы е с л о в а: антисенс-олигодезоксинуклеотиды, комплексы полиэлектролитов, цитотоксичность, окислительно-восстановительные процессы, прион.

Received 20.01.2021 